\title{
THE IMPROVEMENT OF KAMPONG AS AN INSTRUMENT TO MITIGATE FLOODS IN SURABAYA
}

\author{
Sarkawi B. Husain*
}

\begin{abstract}
The improvement of kampong - a residential area Inhabited mostly by the lower class in a town or city - was one of the efforts to prevent flood in the city of Surabaya. The effort was not only related to its contribution to minimize the flood but it also had many aspects. The serious attention to kampong improvement from the Dutch colonial government only appeared in the second decade of the 20th century. When the city of Surabaya was occupied byJapanese troops from March 8th, 1942 untill the independence revolution, the attention to the kampong improvement stopped and many kampongs were destroyed by the war. An effort to restore them resumed in 1950s when everything retuned to normal. To intensify the program of kampong improvement, the W.R. Supratman project was launched following the establishment of Kampong Improvement Project (KIP). One of the criteria to determine a kampong that needed to be restored is whether it was always flooded or not. Nevertheless, the kampong improvement did not really solve the flood problem thoroughly. However, an evaluation shows that this project has made a significant contribution to minimizing the flood in the city of Surabaya.
\end{abstract}

Keywords: flood, kampong improvement, Surabaya

\begin{abstract}
ABSTRAK
Perbaikan kampung adalah salah satu upaya untuk menanggulangi banjir di Kota Surabaya. Upaya tersebut tidak hanya berkaitan dengan kontribusinya dalam mengurangi banjir, tetapi memiliki banyak aspek. Perhatian pemerintah kolonial terhadap perbaikan kampung baru tampak secara serius dalam dasawarsa kedua abad XX yang ditandai dengan dimulainya program perbaikan kampung pada tahun 1924. Ketika Kota Surabaya jatuh di tangan tentara Jepang pada tanggal 8 Maret 1942 hingga revolusi kemerdekaan, perhatian terhadap perbaikan kampung benar-benar terhenti dan banyak kampung mengalami kerusakan akibat perang. Upaya perbaikan baru dimulai kembali pada tahun 1950-an, yakni setelah kondisi mulai normal kembali. Untuk mengintensifkan program perbaikan kampung, pada tahun 1969 diluncurkan Proyek W.R. Supratman disusul dengan dibentuknya proyek Kampung Improvement Project (KIP). Salah satu kriteria kampung yang akan diperbaiki dalam proyek tersebut adalah apakah wilayah tersebut merupakan kampung yang selalu dilanda banjir. Perbaikan kampung memang tidak dapat menyelesaikan persoalan banjir secara tuntas, tetapi evaluasi yang dilakukan menunjukkan proyek ini mempunyai kontribusi yang cukup signifikan dalam mengurangi banjir di Kota Surabaya.
\end{abstract}

Kata Kunci: banjir, perbaikan kampung, Surabaya

\footnotetext{
* History Department, Faculty of Humanities, Universitas Airlangga, Surabaya
} 


\section{INTRODUCTION}

Long before the Dutch colonial administration had control over this region, Surabaya had grown and becomeone of the important cities in Nusantara (the Indonesian archipelago). It was developed when H.W. Daendels became the Governor General of the Netherlands East Indies (January $5^{\text {th }}, 1808$ - May $\left.15^{\text {th }}, 1811\right)$. During the period of this $36^{\text {th }}$ Governor General, Surabaya was maked to be a small European city. It had been developed into a trade and port city. Various kinds of city infrastructures were built, such as Post Highway (Grote Postweg) connecting Java Island's northern coast cities, extending from Anyer to Panarukan (Handinoto, 1996:36-37; Husain, 2010:16).

Nevertheless,Surabaya, one of the big cities in Nusantara, that is dividedby theMas River, surrounded by other smaller rivers is always flooded. The flood is not a new phenomenon. In his two books published in 1931 and 1936, G.H. von Faber revealed that every year Surabaya facedflood whenever theBrantas River and its streams overflowed. Therefore, an advisory commission was established in 1811. This commission suggested threesolutionsto mitigate the flood in the city of Surabaya, i.e. (1) widening of Porong River to channel the water of Brantas River in order thatit does not flow into the rivers in Surabaya, (2) making canals, gutters, and drainage; and (3) directing the waterfrom the city rivers to the floodgate of Wonokromo through Wonokromo canal.The canal that is often called the Jagir River was built in 1856 and completed in 1898(Faber, 1936:169).

Meanwhile, there are several causes leading of floods taking place during the post-colonial era. They are, among others things, high rainfall commonly in of January and February, the silting up of drainage and boezem Morokembangan that were built by the Dutch administration, the sedimentation of the Mas River, the so-many illegal shelters along the river banks, the blockage of drainage due to the garbage accumulation, and the breakage of a number of pumps (Dick, 2002: 226-227). Nevertheless, based on the earlier sources obtained, the floods that took place in the $20^{\text {th }}$ century weremuch worse than those in the previous period.
Since the colonial era, efforts to solve the flood have been made. They are, among others thungs, normalizing rivers, building drainage, improving the existing drainage, providing water pumps, improving kampongs, etc. Kampong improvement as one of the efforts to solve the flood in the city of Surabaya is an interesting point to notice because it is not only related to how significant it is to solve the problem but the project also has something to do with many aspects. During the colonial era, for instance, kampong improvement, more popularly called kampung verbetering, facedthe problems of not only the limited fund but also the land status of the respective kampongs. Therefore, in addition to being aimed atdiscoveringthe contribution of kampong improvement from one period to another tothe flood mitigation in the city of Surabaya, this article is also aimed atdiscovering several aspects related to problems that have existed since he colonial era up to the present. This article is divided into five parts, i.e. (1) kampongs improvement during the colonial era; (2) kampongs during the Japanese occupation and independence revolution; (3) kampongs improvement between 1950 and 1965; (4) kampong improvement after 1965untill the establishment of W.R Suprtaman Project and KIP-Urban; and (5) kampong improvement and flood.

\section{LIMITED IMPROVEMENT: KAMPONG IMPROVEMENT DURING THE COLONIAL ERA}

Between the end of $19^{\text {th }}$ century and $20^{\text {th }}$ century, a number of kampongs inhabited by the native people of the city were susceptible to flood. ${ }^{1}$ The attention that the colonial administration paid to the condition of kampongs in Indonesia, including the ones in Surabaya, first appeared in the second decade of $20^{\text {th }}$ century. According to Amir Karamoy, it was not clear why the colonial administration suddenly paid attention to the lives of kampong people. However, it was assumed that it was related to the development of political ethics in The Netherlands. Another assumption was that the healthy kampong was very important for the colonial society, was of primary importance for the colonial administration itself (Karamoy, 1984:25). 
Such an assumptions, particularly the latter, is understandable because in the second decade of $20^{\text {th }}$ century there were so many epidemic diseases overwhelming the city, especially malaria and bubonic plague. Forexample, in March 1915, the gemeente of Surabaya ordered to unload a kampong in Kali Mas SS (Staatsspoor) that infectedplague epidemic. As a substitute, a new kampong was established in the area. According to the city administration, the unloadof the kampongwas the only way to wipe the plague out of the area (Pewarta Soerabaia, 26-3-1915). In January the following year, eleven people or so, including one European, were foundinfectedby the plague disease. Five of them finally died (Pewarta Soerabaia, 7; 15 and 24-1-1916).

To prevent several diseases from becoming epidemics and to maintain the health of people, it was in 1916 that Plaatselijk en GezonheidsidentsP.G.D. (Local Health Agency), a part of the Provincial Health Agency of East Java, was established (Tantri, 2010:52; Faber, 1936:289). Following theeradicationof diseases in 1920, the kampong improvement in the city of Surabaya was programmed in 1924 by allocating f600,000 for repairing drainage and water channels. In the following year (1925), a more systematic kampong improvement began to be implemented by building new drainage, bathrooms, water pump stations, and public washing spots and toilets. To finance all these repairs and constructions, the city administration allocated f100,000 annually (Faber, 1936:156; Silas, 1982:9).

A more perfect kampong improvement was also implemented by the city administration after the issuance of guidelines made by the Technical Division and People Health Agency (Technische Afdeeling van de Dienst der Volksgezondheid) in 1927. The guidelines stated that a half of the improvement cost would be provided by the agency. The improvement made during this period comprised of two things. The first was the drainage improvement. The improvement was made up of the installation or construction of new drainage connected with the existing drainage in the city. The improvement did not only deal with the kampong drainage but also with bathrooms, washing spots, and toilets. The second was the road improvement. The improvement was in the form of dividing the road for vehicles and pavement (Faber, 1936:156). The kampong improvement was only limited to the kampongs belonging to the "government", but did not cover the kampongs situated on private land although the kampongs were located on the gemeente area. The improvement of kampongs situated on private land was the responsibility of the land owner. However, the government encouraged the land owner to make any improvement.

In addition tothe cost, another constraint gemeente faced in improving kampongs was that there were so many autonomouskampongs under the authority of the city administration. In other words, there was dualism in managing the region. ${ }^{2}$ According to von Faber, the idea to abolish autonomy kampongs had been long in the mind of gemeente. Still, because of being absorbed in improving the kampongs under their authority, gemeente could not manage to realize the abolishment (Faber, 1936:162). To the city administration, the unification in management would make it easier to handle the dirty and unhealthy environment. However, this effort was challenged by the people, including those belonging to volksraad. In view of the native people, such unification was just an effort of gemeente to showhow they work forthe native people. In addition, they were suspicious about this effort as a means of increasing the city income by charging various taxes (Basundoro, 2013:258; Swara Oemoem, 15: 25-10-1930; Swara Oemoem, 15-11-1930). A number of challenges from the people ended with the issuance the government decision No. 21, dated October 21, 1930 and it was effective as of January 1, 1931. With this decision, all kampongs were managed by gemeente Surabaya. The decision also ended the dualism in managing kampongs that had been in existence in the city of Surabaya (Silas, 1982:10; Faber, 1936:162). ${ }^{3}$

Meanwhile, 590 hectares of government kampongs and 100 hectares of private ones had been improvedutill 1931. The kampong drainage and sanitation improvement was made to be taken into the main priority. In 1932, the work began by improving the area located between two riverbanks , i.e. the one located on Citadel Straat and Handel Straat. It covered an area of 69 hectares, in 
which two large kampongs were located, i.e.Ampel and Nyamplungan. It cost around f283,940 to improve the area (Faber, 1936:161).

\section{KAMPONG AND ITS IMPROVEMENT DURING POST COLONIAL ERA UNTILL 1965}

During the Japanese occupation, the kampung improvements carried out by the Dutch colonial government actually stopped. On the contrary, efforts to face the coming war were intensively made. What they did was not related to activities to improve city facilities. They focused on strengthening defense by digging land for protecting themselves from bomb attack (Soeara Oemoem, 22-1-11941; 24-8-1941). ${ }^{4}$ Pada saat pendudukan Jepang, perbaikan kampung yang dilakukan oleh pemerintah kolonial Belanda benar-benar berhenti.

From Japanese occupation until the independence revolution (Frederick, 1986:115), all efforts to improve kampongs stopped completely. In addition On the contrary, a lot of kampongs were damaged by because of the war. One of the kampongs that was were badly damaged by because of the war was Wonokromo. Before the Netherlands began the war against Japan, Wonokromo had been prepared to be a very sturdy as adefense area. According to an analysis, the southern part of the village would become the entrance for the Japanese troops into the city of Surabaya. Therefore, a hundred of people's houses located in Wonokromo, stretching from the west of the bridge to Karangredjo and extending for about 1,500 meters in length, were scorched earth. The people of the respective area were removed to safer places. After the war was over, they moved back to the area of Wonokromo but they could not find their houses since they had been leveled to the ground. Therefore, they built shacks along both sides of Brantas River on the west of the bridge to shelter. Consequently, the kampong of Wonokromo turned into a dirty area. Before the war, it was not so damaged (Harian Umum, 4-8-1950).

In addition to the aftermath of war, the destruction of kampong was also caused by the fast population growth. In 1950, the population of Surabaya was 714,898 people. By the end of 1950 s, the population of Surabaya had almost reached up to nearly 1 million people. According to Silas, the people of low economic level contributed mostly to the population growth. One of the consequences was that the kampongs kept growing. They were getting wider and wider because of the emergence of "illegal kampongs" and the population density as well. However, such a condition was not accompanied with the ability of the city government to serve the growing number of people because of the limited budget (Silas, 1982:13). ${ }^{5}$

In the condition of limited budget, the government, under the coordination of City Public Work Agency, was making a kampong improvement little by little in the context of emergency measures. The improvement was not only made by the government but also by the people in a more limited scale. In 1950, for example, the city government was planning to improve a number of kampongs, such as Gubeng, Klingsingan, Ketandan, Kebangsren, Keputran, and Pacarkembang. All those kampongs cover an area of 17.50 hectares. The budget allocated to improve them was Rp 600,000,-. In addition to improving kampongs, the government also allocated some fund to buy the land for the construction of drainage in Greges, PlosoBogen, Oro-oro, Gersikan, karanggayam, and Pacarkembang. All the land needed for the construction of drainage was about 100 hectares (Suara Rakjat, 28-4-1951). However, because of the limited budget, several new kampongs were just improved in the following year. ${ }^{6}$

Meanwhile, in the 1952 Kampung Improvement Plan proposed by the City Public Work Agency, in that time headed by Ir. Tan GioknTjiauw, the kampongs that were in need of improvement covered an area of 1,000 hectares or so. The number of them was 76 kampongs. Of all those kampongs, 27 of them, an area of about 408.77 hectares, were found standing on the land belonging to the private. It cost between Rp 40,000,00 and Rp 50,000,00 to improve one hectare of the area. The cost did not include the one for making the main drainage and supporting drainages. It was estimated that the budget allocated for the kampong improvement was 
Rp 2,000,000,00 annually. Therefore, it was not impossible to complete the kampong improvement project in 20 years. ${ }^{7}$

Another constraint that made the kampong improvement hard to realize was related to the land purchase. The land would be used for making drainage and roads. A lot of large areas were not equipped with the main drainage for water sewage. In addition, it was really difficult to improve the land without its "verhang" and the one located on lower parts. To realize it well, "bemaling" equipped with electric water pumps was needed (Obor Surabaya, 12-9-1952).

It seemed that such constraints did not make the people of the area withdraw their obsession to have their kampong improved. It was proven with the so many proposals submitted by the people living in the kampongs both on the land belonging to the government and private. The people whose kampong was written on the list of the 1952 Urgent Kampong Improvement could not wait to have their kampong improved. On the other hand, those whose kampong was not included on the list kept on submitting proposals to the government to have their kampong improved soon.

In addition to the problem of limited budget, the kampong improvement also faced another problem related to the status of the land. According to the government, it was the land owners who were responsible for the improvement of the kampong situated on private land. Meanwhile, they did not have enough money for the kampong improvement because they could not make any money from their land. It was the case after, especially, AMACAB (Allied Military Administration Civil Affairs Branch) did not allow the private land owners to ask the people living on houses built on their land to pay for the rent. ${ }^{8}$

What happened to the kampong of Plemahan was a case example. It was situated on the private land belonging to N.V. Bouw-en Handel Maatschappij, The GiokNio, Kembang Djepoen 74. The case first emerged when the people of Plemahansubmitted a proposal for their kampong improvement to the City Government through the City Public Work Agency. In response to this proposal, the mayor of the city of Surabaya in that time, Doel Arnowo, ordered the head of City Public Work Agency and the section head of Pamong Pradja along with RT (Rukun Tetangga/Neighborhood Association) to make an investigation whether the land owners charged for the rent or not so that they were not able to make any improvement for their kampong. ${ }^{9}$

In response to the request of the mayor, the head of the City Development Agency, an agency in charge of private land in the city of Surabaya, proposed three points: (1) to keep the people living in the area healthy, it was necessary to do the area cleaning and the maintenance of the existing drainage; (2) based on the Regulations of Building Structures, article 3, N.V. Bouwen Handel Maatschappij, The GiokNio, the owners of the land, were ordered to do the area cleaning and the maintenance of the drainage located on the respective kampong; and (3) the Municipality would be responsible for the cost of the works. Nevertheless, they were charged for the compensation that had to be paid every month. ${ }^{10}$

Based on the suggestions of the City Development Agency, on December $6^{\text {th }}$, 1950 , the City Mayor eventually sent a letter to N.V. Bouwen Handel Maatschappij, The GiokNio, the owners of the private land, stating that they had to do the area cleaning and the maintenance of the drainage located on the respective kampong. However, they had an objection to do the instruction of the mayor because all private land owners did not get any income from their land. They were prohibited by AMACAB to charge for the rent from the people living in houses on their land. Therefore, the land owners requested thatthe area cleaning and the maintenance of the drainage on the private land should be implemented and financed by the city government or the people living in houses in that kampong. ${ }^{11}$

The case of the kampung of Plemahan situated on private land also happened in other kampongs. Based on the letter of the head of the City Public Work Agency and it was sent to the chairman of DPD of Surabaya Metropolitan dated January $30^{\text {th }}$, 1952, there were 27 kampongs, an area of about 408.77 hectares, being situated on private land. The list of kampongs situated on private land is shown on Table 1 as follows. 
Table 1

Kampongs Situated on Private Land and In Need of Improvement

\begin{tabular}{|c|c|c|c|}
\hline No. & Name of Kampong & $\begin{array}{l}\text { Width } \\
\text { (ha) }\end{array}$ & $\begin{array}{l}\text { Estimated Cost of } \\
\text { Improvement (Rp) }\end{array}$ \\
\hline 1. & Muteran & 1.601 & 64,000 \\
\hline 2. & Gedong-Banger & 1.70 & 68,000 \\
\hline 3. & Kalibutuh & 3.90 & 156,000 \\
\hline 4. & Plemahan DS & 42.27 & $1,891,000$ \\
\hline 5. & Bagong & 2.42 & 97,000 \\
\hline 6. & Dinojo & 3.80 & 772,000 \\
\hline 7. & Blauran (Gg. I-II) & 0.84 & 34,000 \\
\hline 8. & Srengganan (Gg. I, II, III,-Kidul) & 1.04 & 42,000 \\
\hline 9. & $\begin{array}{l}\text { Kepatihan (Gg. IV, V, VI, VII, VIII, X,- Pasar } \\
\text { Besar Wetan Gg. II and T. Bejan Gg. IV }\end{array}$ & 0.60 & 24,000 \\
\hline 10. & Gembongsarswie & 0.50 & 20,000 \\
\hline 11. & Krembangan-Tengah & 0.70 & 28,000 \\
\hline 12. & Kalongan-Sajang & 0.40 & 16,000 \\
\hline 13. & Bibis Pasarean & 0.40 & 16,000 \\
\hline 14. & Kalisari Gg. III & $*)$ & 26,000 \\
\hline 15. & Kalianjar Buntu I, II & $*)$ & 43,000 \\
\hline 16. & Kalongan-Kidul & 0.94 & 38,000 \\
\hline 17. & Krembangan-Kidul & 0.40 & 16,000 \\
\hline 18. & Kp. Dukuh Gg. Buntu & $*)$ & 2,000 \\
\hline 19. & Djuwingan Manjar & 35.56 & $1,426,000$ \\
\hline 20. & Kulon Menur, Kalibokor & 4.80 & 192,000 \\
\hline 21. & Djetis, Karangpo, Korowelang, Pulo & 68.35 & $2,734,000$ \\
\hline 22. & Wonokromo DS. Kedunganjar, Kedungkromo & 15 & 600,000 \\
\hline 23. & Patemon, Banju-urip DS. & 162.56 & $6,502,400$ \\
\hline 24. & Pandjaan DS. & 17.70 & 708,000 \\
\hline 25. & Blauran Kidul & 3 & 120,000 \\
\hline 26. & Kembangkuning & 2.20 & 88,000 \\
\hline 27. & $\begin{array}{l}\text { Gungunsari, Pulosari, Karangan, Wonokitri, } \\
\text { and Pakis }\end{array}$ & 33 & $1,320,000$ \\
\hline
\end{tabular}

Note: *) Road improvement only

(Urgent Plan for Kampong Improvement" in the Archive of Surabaya Metropolita (1950-1957), Volume 1, No.322.

Table 2

Kampong Improvement Project in Progress and Completed in 1952

\begin{tabular}{|c|c|c|c|c|}
\hline No & Name of Kampong & $\begin{array}{c}\text { Land } \\
\text { Width (ha) }\end{array}$ & Estimated Cost (Rp) & Note \\
\hline 1. & Ketandan/Kebangsren & 8.35 & 330,400 or $37,333 / \mathrm{ha}$ & Completed \\
\hline 2. & $\begin{array}{l}\text { Ploso Bogen/Gersikan/ } \\
\text { Kapskrampung and its } \\
\text { surrroundings (urgent } \\
\text { improvement without } \\
\text { drainage) }\end{array}$ & $+/-88.75$ & 269,000 or $3,331,27 / \mathrm{ha}$ & Completed \\
\hline 3. & $\begin{array}{l}\text { Kapasan/Tuwowo/ } \\
\text { Rangkah/ and } \\
\text { Karangasem (urgent } \\
\text { improvement without } \\
\text { drainage) }\end{array}$ & $+/-70.50$ & 249,000 or $3,531,92 / \mathrm{ha}$ & Completed \\
\hline 4. & $\begin{array}{l}\text { Kedungturi/ } \\
\text { Kedungrukem/ } \\
\text { Embong Malang and } \\
\text { its suroundings (urgent } \\
\text { improvement without } \\
\text { drainage) }\end{array}$ & $+/-50.57$ & 407,000 or $8,048,25 / \mathrm{ha}$ & Completed \\
\hline 5. & Kembang Jepun & 2.7 & 108,000 or $40,000 / \mathrm{ha}$ & in progress \\
\hline
\end{tabular}

\begin{tabular}{llccc}
\hline No & Name of Kampong & $\begin{array}{c}\text { Land } \\
\text { Width (ha) }\end{array}$ & Estimated Cost (Rp) & Note \\
\hline 6. & Karangtembok & $+/-6.59$ & 284,000 or $40,000 / \mathrm{ha}$ & in progress \\
7. & Sidodadi & 1.6 & 64,000 or $40,000 / \mathrm{ha}$ & in progress \\
8. & Dinojo & 1.93 & 772,000 or $40,000 / \mathrm{ha}$ & in progress \\
\hline $\begin{array}{l}\text { Source : Archive of KBS (1950-1957), } \\
\text { 5-8-1952 }\end{array}$
\end{tabular}

As it has been stated above, the number of kampongs, situated on both the government and private land, that needed to be improved was of imbalance with the financial support from the government. Therefore, the city government ordered the City Public Work Agency to make urgent plans on kampong improvement in 1952. They would submit the proposal to DPRDS for approval. After undergoing intensive talks between the City Government and DPRDS, through its decision dated August 27 $7^{\text {th }}$, 1952, DPRDS made an agreement to improve eight kampongs in $1952 .{ }^{12}$ Those eight kampongs that were in need of improvement were included on Table 2.

The kampongs that were declared to have been completely improved are listed from numbers one to four on Table two. Nevertheless, several newspapers reported that the improvement of the kampongs Ketandan and Kebangsren, located between Tunjungan Street/Tanjunganom and Embong Malang, was just started in the second week of June 1953. Meanwhile, the improvement of the kampongs listed from numbers two to four reached up to between $30 \%$ and $95 \%$ till June 1953 (Pewarta Soerabaia, 18-6-1953; Suara Masjarakat, 19-6-1953; Java Post, 196-1953). This fact shows that the coordination among institutions of the City Administration of Surabaya was weak, particularly the one involving the City Public Work Agency, DPDS (Dewan Pemerintah Daerah Sementara/Provisional Regional Administration Board), DPRDS (Dewan Perwakilan Rakjat Daerah Sementara/Provisional Regional House of Representatives) of the city of Surabaya.

Under certain circumstances, the kampong improvement could not solve the problem thoroughly, especially if the source of the problem dealt with drainage, like the one happening in Greges River. Such a condition was revealed in the letter forwarded to DPDS KBS from the head of the City Public Work Agency. It revealed that 
the condition of the kampong KedondongKidul was dependent on the uncompleted normalization project of Greges River. Therefore, the kampong improvement was considered ineffective despite the improvement of the kampong drainage but without the incomplete project of the normalization of Greges River. Considering that the project was not completed in a short time, the City Public Work Agency suggested that it was necessary to make an emergency improvement at the kampong Kedondong Kidul to prevent worse situations from happening. The motion was agreed by the city government of Surabaya by allocating the fund of Rp 36,000,00. ${ }^{13}$

Unlike the kampong Kedondong Kidul whose improvement received immediate attention, it took longer time, between one and two years, to improve several other kampongs. It was due to not only the limited budget but also the weak coordination among the city government institutions. The weak coordination was shown with the case of drainage improvement and road construction at the kampongs Wonorejo I and Wonorejo III. On the case of kampong improvement of Wonorejo III, for example, the city government had to send a letter of warning five times to the Head of City Public Work Agency. In another word, it took about eight months for the city government to get the kampong improvement plan confirmed (September 21, 1953 - May 25, 1954). It was interesting to note that the reply the Head of the City Public Work Agency sent eight months later did not show any regret. In his reply, the Head of the City Public Work Agency revealed that the kampong improvement of Wonorejo could not be implemented because of other projects that needed more attention, such as the market development project of WonokromoBaru and kampong improvement projects in line with the urgency 1952 that was approved by DPRDS. In addition to the reason mentioned above, the City Public Work Agency was also puzzled because there was a pressure to improve kampong Patemon of which the condition was much worse than that of Wonorejo. However, Patemon belonged to private kampong. ${ }^{14}$

Meanwhile, the people of several kampongs did the community self-help to prevent their kampongs from being in poorer condition even though they had submitted proposals several times for the improvement of their kampongs but there was no response to their proposals. This is like what the people from the kampong of Kedunganjar did. Between 1950 and 1957, they were submitting their proposals several times to the municipality to receive some attention for their kampong improvement. However, no response was accepted till 1957. Therefore, with the help of several benefactors, they did the community self-help by undergoing the road improvement. They spent Rp 5,500,00 on it (Harian Umum, 25-6-1957).

On the other hand, according to Silas, the condition of kampongs by the change of the decades from 1950s to 1960s kept decreasing and was getting worse and worse. He saw that such a condition was aggravated by the political situation of the time that was signed with the friction of power balance. There was a tendency that the city government let people from villages come into the city without any obstruction. There was a strong assumption that they were purposefully invited to come for political interest. They were expected to vote for a certain political party (Silas, 1982:14). ${ }^{15}$ Silas also added that until mid.1960sthe condition of the settlement of people with low income was getting worse. Indeed, it was made so intentionally. It was clearly seen, he said, from the emergence of illegal settlement along both large and small drainage, parks, fields, and uncontrolled buildings. Such a condition reached the peak when there was a riot breaking, popularly called G $30 \mathrm{~S} / \mathrm{PKI}$. The poor condition began to withdraw in early 1966 (Silas, 1982:14).

\section{KAMPONG IMPROVEMENT OF THE POST 1965: FROM THE DEMOLITION OF ILLEGAL BUILDINGS AND SETTLEMENT, W.R. SUPRATMAN PROJECT TO KIP- URBAN}

After all efforts to improve kampongs were experiencing stagnation by the decade change from 1950 s to 1960 s till the affair of G 30 S/PKI, the city life was gradually recovered. For three years since then, all recovery activities were focused on the demolition and condemnation of illegal buildings and shelters. Those living in the shelter located on open spaces that were supposed to be for public 
facilities, paths for fire emergency (brandgang), river banks, and drainage were forced to demolish their own buildings. Otherwise, they would be demolished by civil service.

After the instruction of the Mayor, Lieutenant Colonel Sukotjo, was released, all houses, buildings, and shops built on both sides of Peneleh River were demolished by civil service that were guarded by the state apparatus (Suluh Indonesia, 5-2-1966). The demolition had to be implemented because those buildings were illegally erected or had no permit from the city administration. In addition to having no permit, many buildings were found to have their foundation planted into the land of river bank and that it blocked the water flow in the river (Suluh Indonesia, 4-5-1966). Nevertheless, according to Silas, because of so many illegal shelters and buildings that were found in every corner of the city and they had been in existence since 1950s, many of them were not demolished. They were even made legal by improving them and implementing the process of obtaining the legal document for the land (Silas, 1982:14).

Kampong improvement was the one that was felt by most people. For the kampongs whose majority people had enough income, the kampong improvement project was implemented by applying self-supporting basis. In other words, all cost was the responsibility of local people. Meanwhile, for the kampongs whose majority people earned a little, a program called W.R. Supratman Project was launched in 1969 (Liberty, 1978:21, 1984:26). ${ }^{16}$

To improve the program quality, the Kampung Improvement Project (KIP) Urban II was established in 1976/1977. Unlike the W.R. Supratman Project that relied on the participation of people and the city governmentfor its fund, KIP Urban II used the fund from APBN (Anggaran Pendapatan dan Belanja Negara/National Budget),
APBD I (AnggaranPendapatandanBelanja Daerah I/Provincial Budget), APBD II(AnggaranPendapatandanBelanja Daerah II/ City Budget), and soft loan with low interest from the World Bank. With the presence of the KIP Urban II, it did not mean that the W.R. Supratman Project was terminated. It remained to be going on, particularly in the kampongs whose people could afford to finance up to 50 percent. Meanwhile, KIP Urban II took the priority over the people with low income and the ones who could not afford to provide fund up to half of the fund required (Kompas, 26-5-1992).

In the first year (1976-1977) of the KIP Urban II Program, the improvement was implemented in four kampongs, namely TembokDukuh, Kalibutuh, GubengKlingsingan-Gubeng Masjid, and Karangrejo with the total fund of Rp 500,000,000. KIP Urban II ended in 1979 and continued with KIP Urban III between 1979 and 1983. No KIP Urban IV was implemented, but then continued with KIP Urban V between 1987 and 1990. When KIP Urban V was completed, any activities related to kampong improvement also ended. However, according to SP Sardjono, the Head of Bappem (BadanPelaksana Pembangunan / Development Implementing Board), the program of kamong improvement would be continued with the program of Surabaya Urban Development Project (SUDP) (Herlianto, 1988:4). ${ }^{17}$

In 1996, the City Government of Surabaya again received some aid from the World Bank amounting to seven billion rupiah for the improvement of 17 kampongs. This aid was distributed through the sampling project of Kampong Improvement Project (KIP) Comprehensive. With this project, it was expected that by 2002 the environmental improvement for about 70 kampongs in Surabaya would have been completely implemented (Kompas, 24-7-1996). ${ }^{18}$ 
Table 3.

Realization of W.R. Supratman Project between 1969/1974 and 1982/1983

\begin{tabular}{ccccccccc}
\hline $\begin{array}{c}\text { Budgeting } \\
\text { Year }\end{array}$ & $\begin{array}{c}\text { Number of } \\
\text { Locations }\end{array}$ & $\begin{array}{c}\text { Asphalted } \\
\text { Roads (m) }\end{array}$ & Drainage & $\begin{array}{c}\text { Bridge } \\
\text { (Unit) }\end{array}$ & Dam & People & \multicolumn{2}{c}{ Financing } \\
APBD & K.M.S \\
\hline $1969 / 1974$ & 220 & 187,741 & 137,081 & 41.9 & 49 & - & & $97,580,341$ \\
$1974 / 1975$ & 55 & 8,567 & - & 1,061 & - & - & $12,720,00$ & $20,879,00$ \\
$1975 / 1976$ & 68 & 14,170 & - & - & - & - & $47,380,00$ & $60,162,00$ \\
$1976 / 1977$ & 48 & 14,425 & 1,027 & - & 55 & 54 & $47,583,00$ & $79,643,00$ \\
$1977 / 1978$ & 68 & 15,490 & - & 460 & - & - & $54,841,00$ & $79,390,00$ \\
$1979 / 1980$ & 96 & 21,000 & - & 1,784 & - & - & $147,942,00$ & $74,974,00$ \\
$1980 / 1981$ & 156 & 39,510 & - & 3,915 & - & - & $290,650,00$ & $266,520,00$ \\
$1981 / 1982$ & 92 & 25,853 & - & 4,036 & - & - & $326,224,00$ & $333,000,00$ \\
$1982 / 1983$ & 47 & 21,177 & - & 4,390 & - & - & $221,473,00$ & $300,000,00$ \\
\hline
\end{tabular}

Source: Putroadi, 1974:14 \& 29; Sunarti, 1987:47

KAMPONG IMPROVEMENT AND FLOOD

Considering that the people indeed felt the benefits of the kampong improvement program, many kampongs were waiting in line for it. ${ }^{19}$ Therefore, to decide which kampongs were in need of it was carried out tightly. In short, the selection process included: (1) the review of the existing land use and "outline plan Surabaya 1969"; (2) the observation of formation of housing arrangement and development program; (3) the classification of housing areas to "kampongs" and "non-kampongs".(Kampong here is defined as a city settlement area with low physical standard and low social-economic condition of the people as well); (4) in each kampong, a survey on physical condition, people's attitude toward improvement, age of kampong, and procurement of legal land; (5) and the extension of scorefor especially the evaluation of physical condition. The rank of kampong was then chosen and based on three levels, i.e.: pioneer I with the scores of 40-60; pioneer II with the scores of 20-40; pioneer III with the score of lower than $20 .{ }^{20}$

The score determination on a kampong was based on 14 criteria with the evaluation scale for each criterion, this is $1-3$. Of those 14 criteria, flood is one of the four criteria with the highest weighing score, this is 3 . In addition, according to ChusenChasbullah, Head of BAPPEM KIP (BadanPelaksana Pembangunan Program PerbaikanKampung/Board for the Development Organizer of Kampong Improvement Program) of the time, the kampongs that were prioritized to be improved were old kampongs situated on the region of 11 old sub-districts. Of all those kampongs situated on 11 sub-districts, the highest priority was given to the ones flooded every year, having less supply for drinking water, having high population density, having people with low income, and having inadequate buildings and public facilities (Chasbullah, 1982:163).

One of the kampongs with frequent flood problem was Kedungdoro. Before being improved through the program of UNEP (United Nations Environmental Program), Kedungdoro had also been improved through another version program, this is W.R. Supratman Project. Even though it had been improved, Kedungdoro was still flooded. A survey before the UNEP program was launched shows that 69 kampongs, 34\% of the area, were still often flooded (Salam, 1982:128; Kompas, 6-81976). Because of that condition and its position in the central part of Surabaya, Kedungdoro unsurprisingly received the improvement program again.

As it has been stated before, one of the important criteria for a kampong to receive the improvement program was flood. However, the fund allocated for solving the flood was small. It ranked the fourth after roads for cars, paths, and drinking water. Big fund allocated mainly for the city flood solution was available on the KIP Urban III. Meanwhile, the fund allocated for the kampong flood solution was still small (Silas, 1982:294). However, even though the fund was small, the kampong improvement project was able to minimize the people's suffering from flood that always happened in the kampong. 
According to the evaluation made by Johan Silas, after the launching of the program KIP, $58.5 \%$ of the kampongs were declared to have been relatively freed from flood. The survey was even made during the rainy season with high rainfall (March). $48.8 \%$ of kampongs that was badly flooded decreased to $12.2 \%$ after the program KIP was implemented. The number of RWs free from flood increased from $12.2 \%$ to $46.3 \%$ after the program KIP was implemented (Silas, 1982:295). Johan Silas even added that before the program KIP was implemented, most kampongs in Surabaya were filled up with semi-permanent houses and soil roads without fixed and unclear design. During the rainy season, those roads were merged with gutter (Silas, 1982:295).

For the achievement made by the city of Surabaya in the kampong improvement program, several international appreciations were awarded. They were, among others, Aga Khan Award for Architecture (AKAA), given in 1986 for the kampong of Kebalen, International Council for Local Environment Initiative (ICLEI), given in 1991 as one of the world's 11 cities considered having been successful in developing local initiatives (Budihardjo, 1987:55; Kompas, 12-10-1982). In addition to receiving several appreciations, Surabaya, through the KIP Model, was also taken as an example that was applied by Thailand and a number of African countries (Jawa Pos, 3-1-1986). 24

\section{CONCLUSION}

Flood is a problem that a lot of Indonesian kampongs face. Flood along with kampong dirtiness becomes the cause of epidemic for various diseases such as malaria and plague. In the early times of colonial administration in Surabaya, no serious handling was taken into consideration to the condition that frequently happened. This was due to the limited fund, so many kampongs that needed to be improved, and other various problems. Serious attention began to be paid in the second decade of XX century. In that time, the colonial administration began to provide fund through some program.

During the occupation of Japanese troops, all activities for improving kampong were on a real stop. On the contrary, any effort to face the coming war was intensively undertaken. When the city of Surabaya was really under the control of Japanese troops till the era of independence revolution, any attention paid to improving kampongs was on a real stop. On the contrary, quite a few kampongs were suffered from destruction because of the war. An effort to improve kampong began to be seriously done again in 1950s. But then, it stopped again by the time of decade change from 1950s to 1960s. After the political riot was over, especially the post-G $30 \mathrm{~S} / \mathrm{PKI}$, the city life was gradually recovered. For three years after the riot, all activities were focused on the demolition and condemnation of illegal buildings. Anyone occupying field for public facilities, paths for fire facility (brandgang), river banks, and drainage was forced to demolish his own building. Otherwise, it was the municipality officers who would demolish the building.

To intensify the kampong improvement program, in 1969 a program called W.R. Supratman was launched and followed by another one called Kampong Improvement Project (KIP). This project was aimed at helping the people improve and maintain their kampong by improving the physical environment and developing proper basic facilities. One of the criteria for a kampong to be improved in the project was whether it was flooded or not. In other words, kampongs that were flooded every year were given high priority. Under certain circumstances, kampong improvement could not solve the problem thoroughly. However, the evaluation made showed that the kampong improvement project contributed significantly to minimizing the flood in the city of Surabaya.

\section{REFERENCES}

\section{Archives, Newspaper, and Magazines}

Arsip Kota Besar Surabaja (1950-1957), Jilid I, no. $322 ; 347$

Harian Umum, 25-6-1957; 4-8-1950

Java Post, 27-8-1951; 19-6-1953; 3-1-1986

Kompas, 6-8-1976; 28-9-1977; 29-9-1978; 12-10-1982; 27-11-1987; 16-1-1988; 21-12-1988; 14-21989; 26-6-1996; 24-7-1996; 1-11-2000.

Kotapradja, No. 4, Tahun VIII, 1979; No. II-12, tahun VII, 1978

Liberty, No. 1065, 2-2-1974; No. 1309, 7-10-1978 
Obor Surabaja, 5-8-1952; 12-9-1952

Pewarta Soerabaia, 26-3-1915; 15-1-1916; 24-1-1916; $18-6-1953 ; 7-1-1916$

Putusan DPRDS, No. 88/DPRDS, tertanggal 27 Agustus 1952 tentang Rencana Urgensi Megenai Perbaikan Kampung Tahun 1952.

Soera Oemoem, 22-1-1941; 24-8-941

Suara Masjarakat, 19-6-1953

Suara Rakjat, 28-4-1951; 25-8-1951; 25-11-1951

Suluh Indonesia, 5-2-1966; 4-5-1966

Surabaya Post, 24-2-1982

Swara Oemoem, 15-10-1930; 25-10-1930; 15-11-1930

Trompet Masjarakat, 7-8-1957

\section{Books and Journals}

Abdul Aziz, Muhammad. (1955). Japan's Colonialism and Indonesia. 'S-Gravenhage: Martinus Nijhoff.

Akhyat, Arief (2006). "The Ideology of Kampung: A Preliminary Research on Coastal City Semarang", Humaniora, vol. 18, no. 1, hlm. 15-26.

Basundoro, Purnawan. (2013). Merebut Ruang Kota. Aksi Rakyat Miskin Kota Surabaya 1900 1960an. Jakarta: Marjin Kiri.

Budihardjo, Eko. (1987). "The Indonesian Experience in the Kampong Improvement Programme", The Indonesian Journal of Geography, Vol. 17 , No. 53, June.

Chasbullah, Chusen. (1982). "Kebijaksanaan dan Organisasi Pelaksanaan" dalam Johan Silas, (peny.). KIP Program Perbaikan Kampung di Surabaya 1969-1982. Suatu Inventarisasi dan Evaluasi (Surabaya: BAPPEM Program Perbaikan Pemerintah Kotamadya Daerah Tingkat II Surabaya.

Faber, G. H. Von. (1936). Nieuw Soerabaia, De Geschiedenis van Indië's voornaamste koopstad in de eerste kwarteeuw sedert hare instelling 1906-1931. Soerabaia: Gemeente Soerabaia.

Frederick, William H. (1986). Pandangan dan Gejolak: Masyarakat Kota dan Lahirnya Revolusi Indonesia (Surabaya 1926-1946). Jakarta:
Gramedia.

Herlianto. (1988). "Proyek Perbaikan Kampung, Apakah Masih Diperlukan?”, Kompas, 16 Januari.

Karamoy, Amir. (1984). "Program Perbaikan Kampung: Harapan dan Kenyataan", Prisma 6, Tahun XIII.

Koesmen, Sjamsu \& Pangestu B.W. (1957). Buku Petundjuk Kota Besar Surabaja Surabaja: Djawatan Penerangan Kota Besar Surabaja.

Putroadi. (1974). "Hasil Pelita I Kotamadya Surabaya di Bidang Prasarana dan Kesra" dalam Liberty, no. 1065.

Salam, Harjono Sigit Bacrun. (1982). "Pengalaman Perbaikan Kampung UNEP”, Johan Silas, (peny.). KIP Program Perbaikan Kampung di Surabaya 1969-1982. Suatu Inventarisasi dan Evaluasi (Surabaya: BAPPEM Program Perbaikan Pemerintah Kotamadya Daerah Tingkat II Surabaya.

Sewindu Membangun Surabaya (1979-1987). (1988). Surabaya: Bagian Humas KMS.

Silas, Johan (peny.). (1982). KIP Program Perbaikan Kampung di Surabaya 1969-1982. Suatu Inventarisasi dan Evaluasi (Surabaya: BAPPEM Program Perbaikan Pemerintah Kotamadya Daerah Tingkat II Surabaya.

Soedradjad, Imam (1979). "Perbaikan Perkampungan di Surabaya", Kotapradja, No. 4, Tahun VIII.

Staatsblad van Nederland Indie. (1931) No. 373.

Sunarti, Endang Titi. (1982). "Perbaikan Kampung Bersama Masyarakat”, Johan Silas, (peny.). KIP Program Perbaikan Kampung di Surabaya 1969-1982. Suatu Inventarisasi dan Evaluasi (Surabaya: BAPPEM Program Perbaikan Pemerintah Kotamadya Daerah Tingkat II Surabaya.

Surabaya dalam Lintasan Pembangunan (1980). Surabaya: Sub Bagian Humas \& Protokol Kotamadya Daerah Tingkat II Surabaya.

Tantri, Erlita. (2010). "Facing Flood in Surabaya, 19061942: Government's Problems, Strategies, and Motives" Master Thesis in History Department Leiden University. 


\section{(Endnotes)}

\section{Notes:}

1. The same condition also happened to many kampongs in Semarang. According to Arief Akhyat, during the rainy season many kampongs were flooded and that the flood could lead to various diseases (see Akhyat, 2006:19)

2 Administratively, till the end of 1930 the area of Surabaya city was still under two authorities, i.e. gemeente, supervising wijk, and regency, supervising inlandschgemeenten or native people residing in kampongs and villages. In that time, there were 26 wijksand 29 villages, each of which was headed by a wijkmeester or wijkhoofder and a village chief. A Wijkmeester was responsible to the burgemeester. A Village chief was responsible to the regent (see Basundoro, 2013:256; Koesman and Pangestu, 1975:114).

3 Law of abolishing InlandschGemeentenSurabaya, also published in Staatsblad van NederlandschInide, No. 373 Year 1931.

4 Anything related about Japanese Occupation in Indonesia can also be obtained in Aziz (1955).

5 For the 1952 budget, for example, the estimated expenditure is Rp 47,427,535,00. Meanwhile, the estimated income is only $\mathrm{Rp} 21,126,950$. Thus, there is a lack of fundforRp 26,300,585,00 (see OborSurabaja, 5-8-1952).

6 Keputran, Pacarkembang, and GubengKlingsingan are three kampongs in which the improvement was prepared in 1952, but realized in 1951. It spent $\mathrm{Rp} 97,300,00$ to improve the kampong of GubengKlingsingan. At the same time, the improvement became an experiment project (see Java Post, 27-8-1951; SuaraRakjat, 25-8-1951; Suararakjat, 25-11-1951).

7 The letter of the Head of City Public Work Agency sent to the Chairman of DPD Surabaja Metropolitan, No. 0103/9, dated 30-1-1952, Archive of Surabaja Metropolitan (1950-1957), Volume I, No. 322.

8 The letter of N.V. Bouw-en Handel Maatschappij, The GiokNio, sent to the Mayor of Surabaya city, dated 15-12-1950. Archive of Surabaja Metropolitan (1950-1957) Volume I, No.347).

9 The letter of the Mayor of Surabaja sent to the Head of City Public Work Agency, No. 0103/13, dated 5-8-1950, Archive of Surabaya Metropolitan (19501957), Volume I, No. 347; the letter of the Mayor of Surabaja sent to the Department Head of Civil Service, No. 0103/14, dated 5-8-1950, Archive of Surabaja Metropolitan (1957-1957, Volume I, No. 347).

10 The letter of Head of City Development Agency of
Surabaja, No. 0103/62, dated 6-11-1950, Archive of Suarabaja Metropolitan (1950-1957), Volume I, No. 347.

11 The letter of N.V. Bouw-en Handel Maatschappij, The GiokNio, reffering to the letter of the Head of City Development Agency sent to the Mayor of Surabaja, No 0103/62, dated 6-11-1950, Archive of Surabaja Metropolitan (1950-1957), Volume I, No.347. The letter of the Mayor of Surabaya, dated 15-12-1950, Archive of Suarabaya Metropolitan (1950-1957), Volume I, No.347.

12 "The decision of DPRDS, No. 88/DPRDS, dated 27 August 1952 on Urgency Plan of Kampong Improvement, Year 1952", in the Archive of KBS (1950-1957), Volume I, No. 22.

13 The letter of the Head of City Public Work Agency, sent to the Chairman of DPDS KBS, No. 0103/37, dated 28-4-1953, Archive of KBS (1950-1957) Volume I, No. 329; the letter of DPDS of KBS, sent to the Head of City Public Work Agency of Surabaja, No. 0103/46, dated 24-7-1953, Archive of KBS (1950-1957) Volume I, No. 329.

14 "Bundle of Kampong and Drainage Improvement in Wonorejo and Patemon" in the Archive of KBS (1950-1957), Volume I, No. 356. The weakness of the coordination between the city administration and its lower agencies is also identified in the case of the plan to improve the roads and gutter in the kampong of Tambakredjo. Since it was proposed long before, it was on August 31, 1953 that the plan was realized, found in the Archive of KBS (1950-1957), Volume I, No. 332.

$15 \mathrm{I}$, the author, did not find strong data about the assumption of Johan Silas. Yet, in July 1957 in the city of Surabaya there was an election for the representatives of DPRD of the municipality. It was PKI that won the election with the total votes of 150,000 , showing an increase of 24,000 votes compared to the ones at the constituent election. See TrompetMasjarakat, 7-8-1957.

16 The name is chosen as to remember the hero merit of arekSuroboyo (Surabaya's guys). He is also wellknown as the composer of the Indonesian anthem. In Surabaya, W.R. Supratman is used to name the project, XX in Jakarta it is called Muhammad HusniThamrin Project. Muhammad HusniThamrin used to be a hero from Jakarta (see Kompas, 28-91977; 27-11-1987).

17 From $1976 / 1977$ to $1985 / 1986$, Rp 9,857,418,00 was spent for the KIP Surabaya. $60 \%$ of the fund came from the World Bank, and the rest came from APBD I \& II and APBN. The fund was used to finance the improvement of 69 kampongs in Surabaya, covering the area of $1,530,5$ hectares. 
There were 670,412 people receiving the benefits of the improvement project. The improvement included the construction of drainage of 375,065 meter in length, the construction of urung-urung of 154,172 meter in length, the construction of 81 roads, the construction of 33 bridges, the construction of 225 MCK (public toilets), the construction of drinking water canal with the length of 183,088 meter, the construction of 13 elementary schools and 10 public health centers (see Jawa Pos, 3-1-1986).

18 This program stopped for one year. In 2001 the program was continued by improving 15 kampongs by using the budget of 1998/1999 (see Kompas, 1-11-2000).

19 By the end of KIP-Urban III, there were still a lot of kampongs listed for improvement. According to the Head of Bappem KIP of Surabaya, ChusenChasbullah, about 662,400 people occupying the kampongs with the area of 1,985 hectares were in need of the KIP. Meanwhile, a few people whom the daily Kompas met for an interview were fond of the KIP project. However, one of the local figures from Tambaksari, Su'ud, felt sorry that the implementation of KIP program was not evenly distributed to the whole kampongs. For example, the citizens of Gang KapasMadya III, the city village of Gading, Sub-district of Tambaksari, kept waiting for the implementation of KIP project in their neighborhood (see Surabaya Post, 24-2-1982; Kompas, 26-6-1996).

20 Behind the success story of kampong improvement project in Surabaya lies the negative story as well. There was still illegal charge leading to the decreasing quality of construction. According to the Daily Kompasinvestigation, the decreasing quality of construction was caused by illegal charge done by persons from the city government. The charge reached up to $15-20 \%$ of the total cost of the project. To the Daily Kompas, several contractors that became the city government partnership said that such amount of illegal charge was common to make the project bid smooth to get and also to cash the fund for the project that had been completed. As a result, the contractors were reducing the quality of construction (see Kompas, 21-12-1988). 